\title{
MASS SPECTROMETRY STUDY OF NONCOVALENT COMPLEXES FORMATION OF ANTIBIOTIC CYCLOSERINE WITH N-ACETYL-D-GLUCOSAMINE AND ASCORBIC ACID
}

\author{
V.A. Pashynska ${ }^{1}$, M.V. Kosevich ${ }^{1}$, A. Gomory ${ }^{2}$ \\ ${ }^{I}$ B. Verkin Institute for Low Temperature Physics and Engineering of the National Academy of Sciences of \\ Ukraine, 47 Nauky Ave., Kharkiv, 61103, Ukraine \\ e-mail: pashynska@ilt.kharkov.ua \\ ${ }^{2}$ Institute of Organic Chemistry of Research Centre for Natural Sciences, 2 Magyar tudosok korutja, Budapest, \\ H-1117, Hungary \\ Submitted December 18, 2019 \\ Accepted January 28, 2020
}

Background: While antibiotic cycloserine (CYS) is widely applied in the treatment of tuberculosis, our knowledge of the drug intermolecular interactions with targeting biomolecules and other drugs remains incomplete. It is believed that the CYS antibacterial activity is related to inhibiting the bacterial cell wall biosynthesis. On the other hand, intermolecular interactions of CYS with ascorbic acid (ASC) molecules is worth of studying taking into account that ASC can be used as supporting vitamin preparation or can be affiliated with the patients nutrition.

Objectives: The purpose of the current model study are to examine biologically significant intermolecular interactions of CYS with N-acetyl-D-glucosamine (NAG) as one of the main component of peptidoglycan of bacterial cell wall and to verify the possibility of noncovalent complexes formation between CYS and ASC molecules using electrospray ionization mass spectrometry (ESI MS) technique. Materials and methods: The objects of the study are model systems composed of CYS and NAG or CYS and ASC prepared in a polar methanol solvent for the ESI MS probing. ESI mass spectra are obtained using the approach earlier developed by us for investigation of the noncovalent complexation of drugs with targeting biomolecules.

Results: The experiments reveal that the ESI mass spectrum of (CYS-NAG) model system contains peaks of protonated molecular clusters of CYS with $\mathrm{NAG}$ : $[\mathrm{CYS} \bullet \mathrm{NAG} \cdot \mathrm{H}]^{+}$and $[\mathrm{CYS} \bullet 2 \mathrm{NAG} \cdot \mathrm{H}]^{+}$. Existing of such peaks in the spectrum testifies to formation of stable noncovalent complexes between CYS and NAG in the studied solution. ESI MS examining of (CYS-ASC) system reveals the noncovalent pair complexation of CYS and ASC molecules confirmed by the recording of intensive peak of $[\mathrm{CYS} \bullet \mathrm{ASC} \cdot \mathrm{H}]^{+}$cluster in the spectrum.

Conclusions: The ESI MS findings point to the possibility of noncovalent complexation of CYS with NAG in the polar media including biological systems. Such complexation between the antibiotic and NAG as component of peptidoglycan of bacterial cell wall is considered to be biologically significant for the process of the cell wall biosynthesis inhibiting by CYS. Stable noncovalent complexes formation between the CYS and ASC molecules is suggested as a potential molecular mechanism of the drugs activity modulation under their joint usage.

KEY WORDS: cycloserine; N-acetyl-D-glucosamine; ascorbic acid; noncovalent complexes; electrospray ionization mass spectrometry.

\section{МАС-СПЕКТРОМЕТРИЧНЕ ДОСЛІДЖЕННЯ ФОРМУВАННЯ НЕКОВАЛЕНТНИХ КОМПЛЕКСІВ АНТИБІОТИКА ЦИКЛОСЕРИНА 3 N-АЦЕТИЛ-D-ГЛЮКОЗАМІНОМ ТА АСКОРБІНОВОЮ КИСЛОТОЮ \\ В.А. Пашинська ${ }^{1}$, М.В. Косевич ${ }^{1}$, А. Гоморі ${ }^{2}$ \\ ${ }^{1}$ Фізико-технічний інститут низьких температур ім. Б.І. Вєркіна Національної академії наук України, просп. Науки, 47, Харків, 61103, Україна \\ ${ }^{2}$ Інститут органічної хімї Наукового иентру природничих наук, Бульвар Мадьяр тудосок, 2, Будапешт, Н-1117, Угорщиина}

Актуальність. Антибіотик циклосерин (CYS) активно застосовується при лікуванні туберкульозу, проте наші знання щодо міжмолекулярної взаємодії молекул цього препарату з біомолекулами-

(C) Pashynska V.A., Kosevich M.V., Gomory A., 2020 
мішенями та з молекулами інших ліків наразі є обмеженими. Вважається, що антибактеріальна дія CYS пов'язана 3 пригніченням процесу біосинтезу клітинної стінки бактерій. Поряд 3 цим певний інтерес становить вивчення міжмолекулярних взаємодій CYS з молекулами аскорбінової кислоти (ASC), оскільки вона може використовуватися як допоміжний вітамінний препарат при лікуванні туберкульозу або знаходитися у їжі пацієнтів.

Мета роботи. Задачами даного модельного дослідження стали вивчення біологічно важливих міжмолекулярних взаємодій циклосерину 3 N-ацетил-D-глюкозаміном (NAG), що є одним 3 головних компонентів полімерного пептидоглікану клітинної стінки бактерій, та перевірка можливості формування нековалентних комплексів між молекулами CYS та ASC за допомогою методу мас-спектрометрії з іонізацією електророзпиленням (МСIEP).

Матеріали й методи. Об'єктами дослідження обрано модельні системи, складовими яких є CYS та NAG або CYS та ASC, розчинені у полярному розчиннику метанолі для МСIEР експериментів. Мас-спектри було отримано з використанням розробленого нами раніше підходу до дослідження нековалентного комплексоутворення між молекулами лікарських агентів та біологічними молекулами-мішенями.

Результати. Показано, що мас-спектр IEP модельної системи (CYS-NAG) містить піки протонованих молекулярних кластерів CYS та NAG: [CYS•NAG•H] ${ }^{+},[\mathrm{CYS} \bullet 2 \mathrm{NAG} \bullet \mathrm{H}]^{+}$. Наявність цих піків у спектрі свідчить про формування стабільних нековалентних комплексів між CYS та NAG у дослідженому розчині. MCIEP дослідження системи (CYS-ASC) виявило утворення нековалентних парних комплексів молекул CYS та ASC, що підтверджується наявністю у спектрі інтенсивних піків кластерів $[\mathrm{CYS} \cdot \mathrm{ASC} \cdot \mathrm{H}]^{+}$.

Висновки. Результати МСIEР експериментів вказують на можливість нековалентного комплексоутворення між молекулами CYS та NAG у полярному середовищі, включаючи біологічні системи. Ми вважаємо, що таке зв'язування молекул протитуберкульозного антибіотика CYS 3 NAG-компонентами пептидоглікану клітинної стінки бактерій може бути біологічно важливим для процесу пригнічення біосинтезу клітинної стінки. Виявлене формування стабільних нековалентних комплексів молекул CYS та ASC в розчині пропонується як потенційний молекулярний механізм модуляції активності цих лікарських засобів при їх одночасному застосуванні.

КЛЮЧОВІ СЛОВА: циклосерин; N-ацетил-D-глюкозамін; аскорбінова кислота; нековалентні комплекси; мас-спектрометрія з іонізацією електророзпиленням.

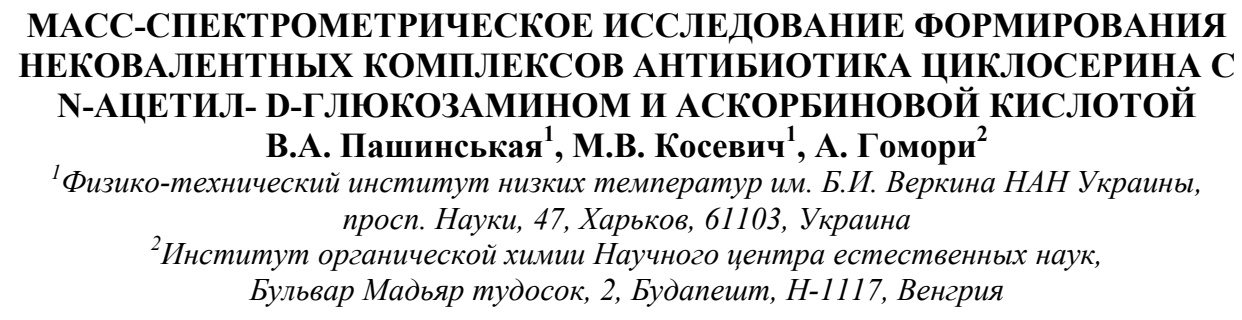

Актуальность. Антибиотик циклосерин (CYS) широко используется при лечении туберкулеза, однако наши знания о межмолекулярных взаимодействиях этого лекарственного препарата с биомолекулами-мишенями и молекулами других лекарств остаются неполными. Предполагается, что антибактериальное действие CYS связано с ингибированием биосинтеза клеточной стенки бактерий. Наряду с этим определенный интерес представляет изучение межмолекулярных взаимодействий CYS с молекулами аскорбиновой кислоты (ASC), поскольку она может применяться как вспомогательный витаминный препарат при лечении туберкулеза или находиться в пище пациента.

Цель работы. Задачами настоящего модельного исследования стали изучение биологически значимых межмолекулярных взаимодействий CYS с N-ацетил-D-глюкозамином (NAG), который является основным составным компонентом пептидогликана клеточной стенки бактерий, а также оценка возможности формирования нековалентных комплексов между молекулами CYS и ASC методом масс-спектрометрии с ионизацией электрораспылением (МСИЭР).

Материалы и методы. Объектами исследования были выбраны модельные двухкомпонентные системы, состоящие из CYS и NAG или CYS и ASC, приготовленные на основе полярного растворителя метанола для МСИЭР анализа. Масс-спектры получали, используя разработанный нами ранее подход для исследований нековалентного комплексообразования между молекулами лекарственных агентов и биомолекулами-мишенями. 
Mass spectrometry study of noncovalent complexes formation of antibiotic cycloserine...

\begin{abstract}
Результаты. Показано, что масс-спектр ИЭР модельной системы (CYS-NAG) содержит пики протонированных молекулярных кластеров CYS и NAG: [CYS•NAG•H] $]^{+}$[CYS•2NAG•H] ${ }^{+}$. Наличие этих пиков в спектре свидетельствует о формировании стабильных нековалентных комплексов CYS и NAG. МСИЭР исследование системы (CYS-ASC) выявило формирование парных нековалентных комплексов молекул CYS и ASC, что подтверждается присутствием в спектре интенсивных пиков кластеров $[\mathrm{CYS} \bullet \mathrm{ASC} \cdot \mathrm{H}]^{+}$.

Выводы. Результаты МСИЭР экспериментов указывают на возможность нековалентного комплексообразования между молекулами CYS и NAG в полярном окружении, включая биосистемы. Считаем, что такое связывание молекул противотуберкулезного антибиотика CYS c NAG-компонентами пептидогликана клеточной стенки бактерий может быть биологически значимым для процесса ингибирования биосинтеза клеточной стенки. Обнаруженное формирование стабильных нековалентных комплексов молекул CYS и ASC в растворе предлагается как потенциальный молекулярный механизм модуляции активности этих лекарственных агентов при их совместном применении.

КЛЮЧЕВЫЕ СЛОВА: циклосерин; $\mathrm{N}$-ацетил-D-глюкозамин; аскорбиновая кислота;
\end{abstract} нековалентные комплексы; масс-спектрометрия с ионизацией электрораспылением.

Antibiotic cycloserine (CYS) is widely used in medical practice to treat a number of infection diseases, foremost tuberculosis and its drug resistant forms [1,2]. At the same time our knowledge on molecular mechanisms of CYS antimicrobial and, in particular antituberculosis activity remains incomplete and requires further advancement anticipating the demand in overcoming of drug resistance of the pathogens [3-6].

It is believed that CYS reveals its antibacterial effect by inhibiting the biosynthesis of bacteria cell wall peptidoglycan and this inhibition may result from multi-targeting action of D-cycloserine in the bacteria cell [3-6], e.g. reaction with enzyme alanine racemase [6] or binding to another enzyme involved in peptidoglycan biosynthesis - D-alanine:D-alanine ligase $[3,4]$. Moreover recently it was shown that the inhibition of D-alanine:D-alanine ligase by D-cycloserine can be proceeded via a distinct phosphorylated form of the drug [4]. Taking into account the continued studies of the mentioned enzymatic mechanisms of CYS antimicrobial activity and sharing the idea that the antibacterial agents can target multiple activities in the bacterial cells metabolism [7,8], we think that from biophysical point of view it would be interesting to investigate the intermolecular interactions of CYS not just with the enzymes of the peptidoglycan biosynthesis, but also with the reagents participated in this crucial for bacteria biosynthetical process.

A purpose of the current model study is to examine the biologically significant intermolecular interactions of CYS with one of the main sugar component of peptidoglycan of bacterial cell wall - N-acetyl-D-glucosamine (NAG) applying electrospray ionization mass spectrometry (ESI MS) technique.

Furthermore, the multi-drugs schemes of therapy of infection diseases are commonly applied presently. A number of supporting preparations, such as anti-inflammatory agents, vitamin preparations, etc, may be used by patients jointly with antibiotic preparations; in this connection the effects of the drugs activity modulation on the molecular level is considered as an important subject to be investigated. In this light another task of the current work is to investigate possible complexation of the CYS molecules with ascorbic acid (ASC), known as vitamin $C$, which can be used in anti-tuberculosis therapy as supporting vitamin medication or could be affiliated with the patient's food.

To examine the problems stated above and to investigate the intermolecular interactions of CYS with its possible targeting molecule of NAG and with ascorbic acid we used ESI MS approach which was developed and successfully applied by us in our previous investigations of the drugs molecules interactions with biomolecules and other biologically active agents [9-12]. 


\section{MATERIALS AND METHODS}

\section{Materials}

In our experiments we used cycloserine produced by company "Enamine" (Ukraine); $\mathrm{N}$-acetyl-D-glucosamine and L-ascorbic acid ( $99 \%$ of purity) were provided by "Sigma-Aldrich" international company. Structures of the compounds under study are presented in Scheme 1.<smiles>N[C@@H]1CONC1=O</smiles>

a

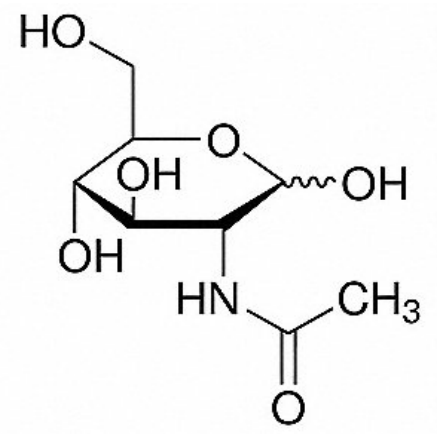

$\mathrm{b}$<smiles>O=C1O[C@H]([C@@H](O)CO)C(O)=C1O</smiles>

c

Scheme 1. Structures of compounds under study: a) cycloserine (CYS);

b) N-acetyl-D-glucosamine (NAG); c) L-ascorbic acid (ASC).

The $5 \mathrm{mM}$ stock solutions of CYS, NAG and ASC were prepared in polar solvent methanol and model systems containing CYS and NAG (1:5 molar ratio) or CYS and ASC (1:1 molar ratio) were obtained by mixing on the appropriate volume parts of the stock solutions.

The mixtures were kept at the room temperature for at least 10 minutes before the ESI mass spectrometric analysis. For spraying procedure in the ESI MS experiments the primary CYS solution to be examined and the model systems (CYS-NAG) and (CYS-ASC) were diluted by methanol to the final $250 \mu \mathrm{M}$ concentration of CYS in each solution.

Note that methanol as the most appropriate solvent is recommended for standard ESI probing of biomolecules and their intermolecular interactions basing on a number of authoritative studies [13-17]. As to noncovalent intermolecular complexes of bioactive molecules, it was shown that their composition in water and methanol-based solutions is similar [17].

\section{Electrospray ionization mass spectrometry}

ESI mass spectra of the model systems under study were obtained in the positive ion mode using triple quadrupole (QqQ) Micromass Quattro Micro mass spectrometer (Waters, Manchester, UK) equipped with the electrospray ion source. This source was operated in the standard ESI mode. The ESI source temperature was set to $120^{\circ} \mathrm{C}$ and the desolvation temperature was $200^{\circ} \mathrm{C}$. The spraying capillary was operated at $3.5 \mathrm{kV}$. The cone voltage value of $10 \mathrm{~V}$ was applied. The analyzed solutions $(20 \mu \mathrm{L})$ were injected into the mass spectrometer at a constant flow rate of $0.2 \mathrm{~mL} \cdot \mathrm{min}^{-1}$ of methanol solvent. The ESI spectra were recorded in the mass range of 100-2000 Da. Data acquisition and processing were performed using MassLynx 4.1 software (Waters, Manchester, UK).

\section{RESULTS AND DISCUSSION}

\section{Electrospray mass spectrometry probing of neat cycloserine solution}

At the first stage of the experimental study the solution of the antibiotic CYS in methanol was investigated by ESI MS. It was established that characteristic ESI mass 
spectrum of the preparation (Fig. 1) contained intensive peaks of the protonated molecule of CYS [Cys $\bullet \mathrm{H}]^{+}$at $\mathrm{m} / \mathrm{z} 103.2$, cationized molecule $[\mathrm{Cys} \bullet \mathrm{Na}]^{+}$at $\mathrm{m} / \mathrm{z} 125.2$ and less intense peak of the protonated CYS dimer $[2 \mathrm{Cys} \bullet \mathrm{H}]^{+}$at $\mathrm{m} / \mathrm{z} 205.4$.

High quality of the obtained mass spectrum of the drug, characterized by a high signal to noise ratio, confirms the applicability of the ESI MS method for investigation of CYS containing model systems, including the systems generated for study of intermolecular interactions of CYS with biologically active molecules, as well as the effectiveness of the ESI MS for CYS identification in different biological and pharmacological samples in any clinical or technological investigations.

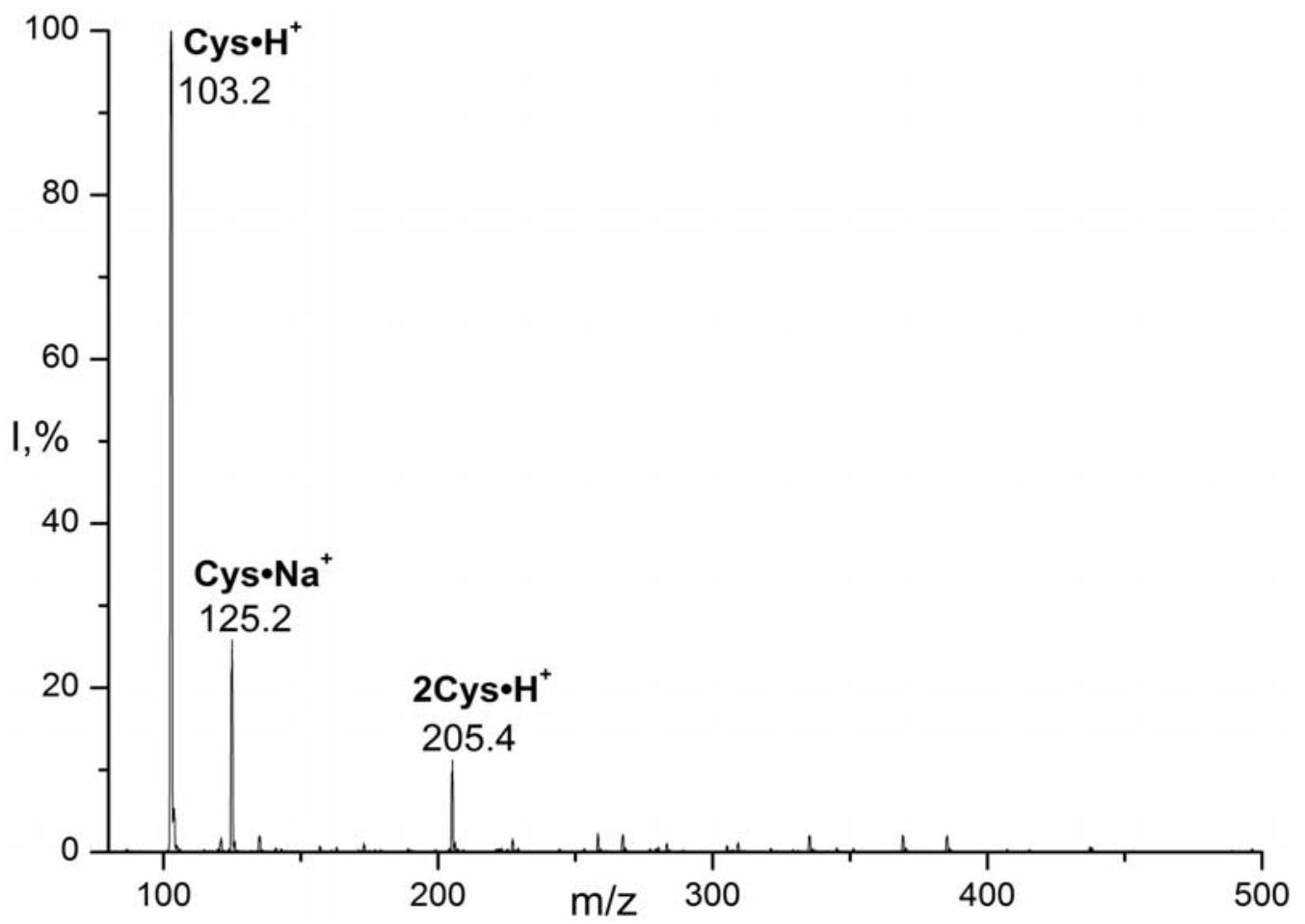

Fig. 1. ESI mass spectrum of CYS solution in methanol.

\section{Electrospray mass spectrometric study of cycloserine- $N$-acetyl-D-glucosamine model system}

At the next stage, the model system of CYS with NAG (1:5 molar ratio) in methanol was probed with the purpose to examine the possibility of noncovalent complexes formation between the molecules of the system components. In the obtained ESI mass spectrum (Fig. 2) the ions characteristic of the individual components of the mixture such as: $[\mathrm{Cys} \bullet \mathrm{H}]^{+}$at $\mathrm{m} / \mathrm{z}$ 103.2, $[\mathrm{Cys} \bullet \mathrm{Na}]^{+}$at $\mathrm{m} / \mathrm{z} 125.2,[2 \mathrm{Cys} \bullet \mathrm{H}]^{+}$at $\mathrm{m} / \mathrm{z} 205.4$ for $\mathrm{CYS}$ and $[\mathrm{NAG} \bullet \mathrm{H}]^{+}$at $\mathrm{m} / \mathrm{z} 222.2$, $[\mathrm{NAG} \bullet \mathrm{Na}]^{+}$at $\mathrm{m} / \mathrm{z} 244.2,[2 \mathrm{NAG} \cdot \mathrm{H}]^{+}$at $\mathrm{m} / \mathrm{z} 443.4,[2 \mathrm{NAG} \bullet \mathrm{Na}]^{+}$at $\mathrm{m} / \mathrm{z} 465.4$ for $\mathrm{NAG}$; were accompanied by the peaks of protonated molecular clusters of CYS with NAG: $[\mathrm{Cys} \bullet \mathrm{NAG} \bullet \mathrm{H}]^{+}$at $\mathrm{m} / \mathrm{z} 324.4$ and $[\mathrm{Cys} \bullet 2 \mathrm{NAG} \bullet \mathrm{H}]^{+}$at $\mathrm{m} / \mathrm{z} 545.6$. $^{2}$

Such molecular clusters recorded in the ESI mass spectrum testifies to the formation of stable noncovalent complexes between CYS and NAG in the studied model system and these complexes stability is sufficient to provide the clusters surveillance under the electrospray ionization processes. The ESI MS findings point to the possibility of noncovalent complexation of CYS with NAG in the polar media, including solutions in polar solvents like methanol or water, that model the media in biological systems. Such intermolecular interaction between the molecules of antibiotic CYS and the NAG components of bacteria 
cell wall peptidoglycan is considered to be biologically significant for the process of the bacterial wall biosynthesis inhibition induced by CYS as well as can affect the drug penetration into the bacterial cell.

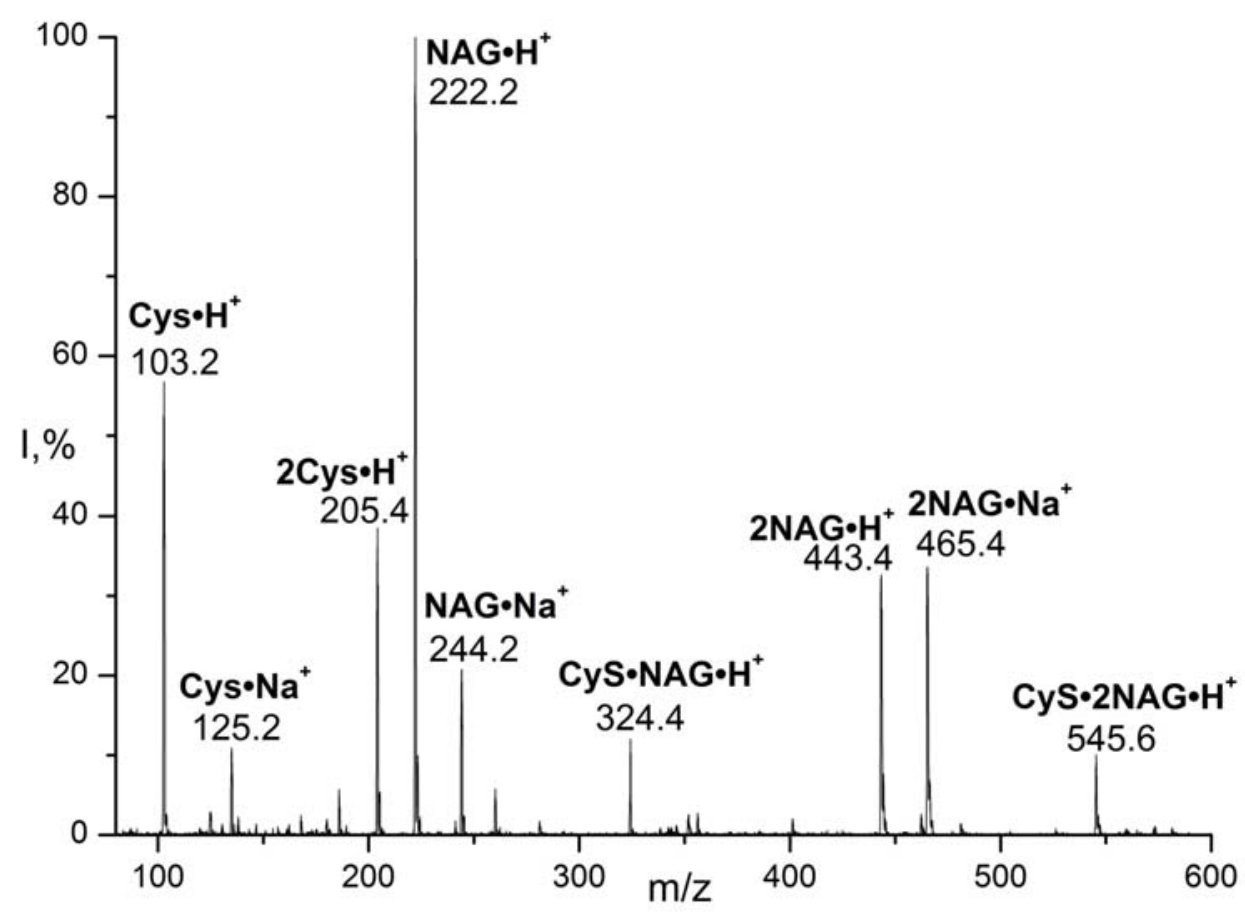

Fig. 2. ESI mass spectrum of (CYS-NAG) model system.

Electrospray mass spectrometry study of cycloserine-ascorbic acid model system

As the second task of this study we investigated the model system containing CYS and ASC. The obtained ESI mass spectrum of the studied system can be seen in Fig. 3.

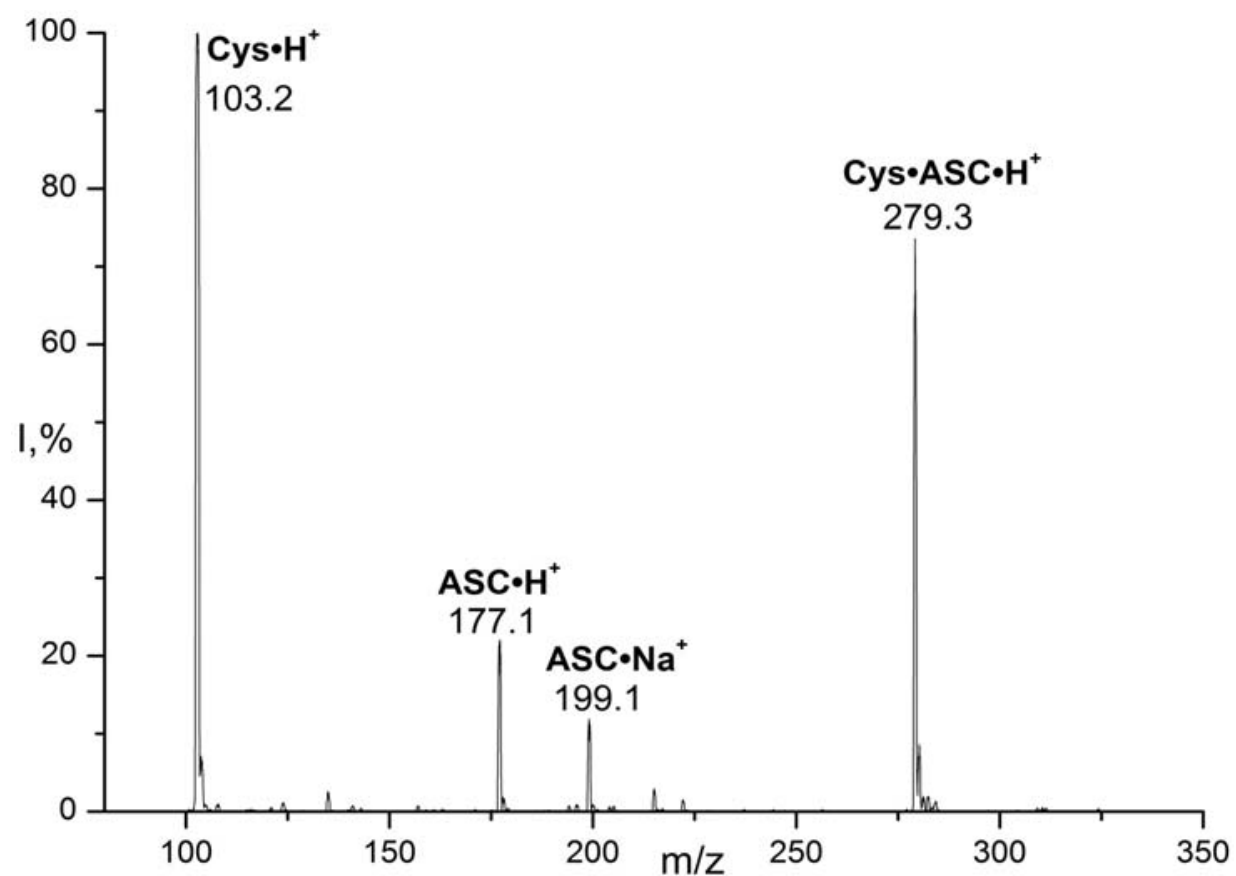

Fig. 3. ESI mass spectrum of (CYS-ASC) model system. 
Mass spectrometry study of noncovalent complexes formation of antibiotic cycloserine...

Similarly to the described above model system of (CYS-NAG), in the spectrum of (CYS-ASC) mixture the characteristic peaks of the system components are present: $[\mathrm{Cys} \bullet \mathrm{H}]^{+}$ at $\mathrm{m} / \mathrm{z} 103.2$ for $\mathrm{CYS}$ and $[\mathrm{ASC} \cdot \mathrm{H}]^{+}$at $\mathrm{m} / \mathrm{z} 177.1$ and $[\mathrm{ASC} \cdot \mathrm{Na}]^{+}$at $\mathrm{m} / \mathrm{z} 199.1$ for ASC. At the same time, neither cationized CYS $-[\mathrm{Cys} \bullet \mathrm{Na}]^{+}$nor $\mathrm{CYS}$ dimer $-[2 \mathrm{Cys} \bullet \mathrm{H}]^{+}$peaks can be found in the spectrum of (CYS-ASC) system (Fig. 3), in contrast to the spectra of the neat CYS (Fig. 1) and (CYS-NAG) mixture (Fig. 2). Absence of the [Cys•Na] $]^{+}$ion in the presence of $[\mathrm{ASC} \cdot \mathrm{Na}]^{+}$ion points to the competition for the metal cation binding in favour of more acidic ascorbic acid, while the absence of CYS dimer peak in the spectrum can be connected with the change of the conditions for CYS dimerization reaction caused in the presence of ascorbic acid in the model system.

The most interesting from the biophysical point of view result is recording in the spectrum of high intensive peak of a cluster of CYS with ASC - [Cys $\bullet A S C \cdot H]^{+}, \mathrm{m} / \mathrm{z} 279.3$, $\mathrm{I}=75 \%$ (Fig. 3). This peak points to the intensive process of formation of stable noncovalent complexes of CYS with ASC molecules in the polar solvent methanol.

Noncovalent complexation revealed between the molecules of cycloserine and ascorbic acid in solvents can modulate the drugs activity under their joint usage.

\section{CONCLUSIONS}

Realization of biologically significant noncovalent complexation of antibiotic cycloserine molecules with the components of bacterial cell wall and with ascorbic acid in polar solvent is proved as the main result of the present model study by means of ESI MS.

The possibility of noncovalent clusters formation between the molecules of CYS and the main sugar component of peptidoglycan of the bacterial cell wall, $\mathrm{N}$-acetyl-D-glucosamine, in polar medium is demonstrated. The intermolecular complexes formation between CYS and peptidoglycan components can play an important role in molecular mechanisms of the bacteria cell wall biosynthesis inhibiting induced by the CYS antimicrobial action.

ESI MS examining of the model system containing CYS and ASC points to the intensive process of formation of the pair noncovalent clusters of the different drugs molecules in the polar solution. Such complexation between the molecules of CYS and ASC under joint usage of the drugs by patients can modulate the individual drugs activity and should be taken into account in medical practice.

The performed mass spectrometry study also confirms the effectiveness of the ESI MS method for investigation of intermolecular interactions in cycloserine containing systems and for the drug identification in the biological and technological solutions in clinical and industrial applications.

\section{ACKNOWLEDGEMENTS}

Authors acknowledge the Program of cooperation between Ukrainian and Hungarian Academies of Sciences for the financial support of the visits of the scientists from B. Verkin Institute for Low Temperature Physics and Engineering of the National Academy of Sciences of Ukraine to the Research Centre for Natural Sciences and the Hungarian Academy of Sciences, where the mass spectrometry experiments were carried out. We also thank Vashchenko O.V. and other colleagues from the Institute for Scintillation Materials of STC "Institute for Single Crystals" of the NAS of Ukraine for providing the cycloserine samples.

\section{CONFLICT OF INTERESTS}

The authors declare that there is no conflict of interest. 


\begin{abstract}
Authors' ORCID ID
V.A. Pashynska (iD https://orcid.org/0000-0001-9786-6828

M.V. Kosevich (iD http://orcid.org/0000-0003-0257-4588

A. Gomory (iD) http://orcid.org/0000-0001-5216-0135
\end{abstract}

\title{
REFERENCES
}

1. Cycloserine. [No authors listed] Tuberculosis (Edinb). 2008 Mar:88(2):100-1. https://doi.org/10.1016/S1472-9792(08)70007-6

2. Perri GD, Bonora S. Which agents should we use for the treatment of multidrug-resistant Mycobacterium tuberculosis? J Antimicrob Chemother. 2004 Sep:54(3):593-602. https://doi.org/10.1093/jac/dkh377

3. Prosser GA, de Carvalho LPS. Reinterpreting the Mechanism of Inhibition of Mycobacterium tuberculosis dAlanine:d-Alanine Ligase by d-Cycloserine. Biochemistry. 2013:52(40):7145-49. https://doi.org/10.1021/bi400839f

4. Batson S, de Chiara C, Majce V, Lloyd AJ, Gobec S, Dean Rea, et. al. Inhibition of D-Ala:D-Ala ligase through a phosphorylated form of the antibiotic D-cycloserine. Nature Communications. 2017:8:1939. https://doi.org/10.1038/s41467-017-02118-7

5. Neuhaus FC, Lynch JL. The enzymatic synthesis of D-alanyl-D-alanine. 3. On the inhibition of D-alanyl-Dalanine synthetase by the antibiotic D-cycloserine. Biochemistry. 1964:3(4):471-80. https://doi.org/10.1021/bi00892a001

6. Lambert MP, Neuhaus FC. Mechanism of D-cycloserine action: alanine racemase from Escherichia coli W. J Bacteriol. 1972 Jun:110(3):978-87.

7. East SP, Silver LL. Multitarget ligands in antibacterial research: progress and opportunities. Expert Opin Drug Discov. 2013 Feb:8(2):143-56. https://doi.org/10.1517/17460441.2013.743991

8. Walsh CT, Wencewicz TA. Prospects for new antibiotics: a molecule-centered perspective. J Antibiot. 2014 Jan:67(1):7-22. https://doi.org/10.1038/ja.2013.49

9. Pashynska VA, Kosevich MV, Gomory A, Vekey K. Model mass spectrometric study of competitive interactions of antimicrobial bisquaternary ammonium drugs and aspirin with membrane phospholipids. Biopolym Cell. 2013:29(2):157-62. https://doi.org/10.7124/bc.000814

10. Pashynska V, Stepanian S, Gomory A, Vekey K, Adamowicz L. Competing intermolecular interactions of artemisinin-type agents and aspirin with membrane phospholipids: Combined model mass spectrometry and quantum-chemical study. Chem Phys. 2015:455:81-7. https://doi.org/10.1016/j.chemphys.2015.04.014

11. Pashynska V, Stepanian S, Gomory A, Vekey K, Adamowicz L. New cardioprotective agent flokalin and its supramolecular complexes with target amino acids: An integrated mass-spectrometry and quantum-chemical study. J Mol Struct. 2017:1146:441-9. https://doi.org/10.1016/j.molstruc.2017.06.007

12. Pashynska VA, Zholobak NM, Kosevich MV, Gomory A, Holubiev PK, Marynin AI. Study of intermolecular interactions of antiviral agent tilorone with RNA and nucleosides. Biophys Bull. 2018:39(1):15-26. https://doi.org/10.26565/2075-3810-2018-39-02

13. Cole R, editor. Electrospray and MALDI mass spectrometry: fundamentals, instrumentation, practicalities, and biological applications. 2nd edition. Hoboken, New Jersey: John Wiley \& Sons, Inc.; 2010. 896 p. ISBN: 978-0-471-74107-7

14. Loo JA. Electrospray ionization mass spectrometry: a technology for studying non-covalent macromolecular complexes. Int J Mass Spectrom. 2000:200(1-3):175-86. https://doi.org/10.1016/S1387-3806(00)00298-0

15. Wyttenbach Th, Bowers MT. Intermolecular interactions in biomolecular systems examined by mass spectrometry. Annu Rev Phys Chem. 2007:58:511-33. https://doi.org/10.1146/annurev.physchem.58.032806.104515

16. McCullough BJ, Gaskell SJ. Using electrospray ionisation mass spectrometry to study non-covalent interactions. Comb Chem High Throughput Screen. 2009:12(2):203-11. https://doi.org/10.2174/138620709787315463

17. Guevremont R, Siu KWM, Le Blanc JCY, Berman SS. Are the electrospray mass spectra of proteins related to their aqueous solution chemistry? J Am Soc Mass Spectrom. 1992 Mar:3(3):216-24. https://doi.org/10.1016/1044-0305(92)87005-J 